\title{
Update on diagnosis and monitoring of cystic fibrosis- related diabetes mellitus (CFRD)
}

\author{
Atualização no diagnóstico e acompanhamento do \\ diabetes melito relacionado à fibrose cística (DRFC)
}

Renata Maria de Noronha', Luís Eduardo Procópio Calliari², Neiva Damaceno ${ }^{3}$, Lucia Harumi Muramatu ${ }^{3}$, Osmar Monte ${ }^{4}$

\section{SUMMARY}

Cystic fibrosis (CF) is the most common recessive autosomal disease among Caucasian. Children with CF have benefitted from advances in medical and nutritional treatments, and this can be gleaned from the improvement in the survival of these patients. The increase in the survival rate brought with it the appearance of co-morbidities related to CF. Nowadays cystic fibrosis-related diabetes (CFRD) is considered the most common complication associated with CF. It can appear as early as infancy or adolescence, and its prevalence can be as high as $50 \%$ in adult patients. Because of its high prevalence, difficulties in early detection and the risks involved, in recent years several studies and consensuses have focused on this condition, adding information about the epidemiology, pathophysiology, prognosis and treatment of CFRD. The main aspects of these new concepts, as well as the current recommendations for its diagnosis and follow-up, will be presented in this study. Arq Bras Endocrinol Metab. 2011;55(8):613-21

\section{Keywords}

Diabetes mellitus; diagnostic; cystic fibrosis; cystic fibrosis-related diabetes; pathophysiology; treatment

\section{SUMÁRIO}

Fibrose cística (FC) é a doença autossômica recessiva mais comum nos caucasianos. Avanços no tratamento da FC acarretaram aumento na sobrevida dos pacientes, que trouxe o aparecimento de comorbidades relacionadas à doença. Atualmente, o diabetes relacionado à fibrose cística (DRFC) é considerado a complicação mais comum associada à FC, podendo aparecer já na infância ou adolescência, chegando a atingir até $50 \%$ dos pacientes adultos. Em virtude da alta prevalência, das dificuldades de diagnosticar precocemente e das graves consequências para os pacientes, nos últimos anos vem crescendo a preocupação com a detecção e o tratamento precoces do DRFC. Vários grupos têm se dedicado a procurar evidências e desenvolver consensos com o objetivo de orientar o diagnóstico e o acompanhamento dessa comorbidade. Neste artigo apresentamos os principais aspectos dessa evolução, bem como as atuais recomendações no acompanhamento de pacientes com DRFC. Arq Bras Endocrinol Metab. 2011;55(8):613-21

\section{Descritores}

Diabetes melito; diagnóstico; fibrose cística; diabetes relacionado à fibrose cística; fisiopatologia; tratamento

\section{INTRODUCTION}

$\mathrm{C}$ ystic fibrosis (CF) is the most common lethal recessive autosomal disease among Caucasians, and represents a prevalence of $1: 2500$ to $1: 4000$ living newborns (1). In 1980, Tsui, Riordan and Collins isolated
1 Pediatric Endocrinology Unit, Pediatric Department of Santa Casa de São Paulo Hospital; Faculdade de Ciências Médicas da Santa Casa de São Paulo (FCM-SCSP), São Paulo, SP, Brazil 2 Pediatric Endocrinology Unit, Pediatric Department of Hospital da Santa Casa de São Paulo, São Paulo, SP, Brazil 3 Pediatric Pneumology Unit, Pediatric Department of Hospital da Santa Casa de São Paulo, São Paulo, SP, Brazil ${ }^{4}$ Discipline of Endocrinology, Clinical Medicine Department; Hospital da Santa Casa de São Paulo, São Paulo, SP, Brazil

Correspondence to: Renata Maria de Noronha Departamento de Pediatria, Santa Casa de Misericórdia de São Paulo Rua Cesário Motta Jr., 112, $5^{\circ}$ andar 01221-020 -São Paulo, SP, Brazil renata-noronha@uol.com.br

Received on 17/Oct/2011 Accepted on 21/Oct/2011 the gene responsible for cystic fibrosis in the long arm of chromosome 7 (7q31.2) (2).

Since the beginning of the 1990s, children with cystic fibrosis have benefitted from advances in medical and nutritional treatments. This may be observed by impro- 
ved patient survival, which today reaches an average of 40 years, in contrast with the life expectancy of less than a one-year survival in the 1950s (3).

Increased survival rate brought forth comorbidities related to $\mathrm{CF}$, such as cystic fibrosis-related diabetes (CFRD), bone diseases and depression $(3,4)$. The first account of oral glucose intolerance (OGI) in patients with CF was published in 1955, and currently CFRD is considered the most common complication associated with $\mathrm{CF}(3,5)$.

In the United States, the prevalence of CFRD is as high as $50 \%$ in adult patients of about 30 years old, and $9 \%$ in children between 5 and 10 years of age, progressively increasing during puberty (6) (Figure 1).

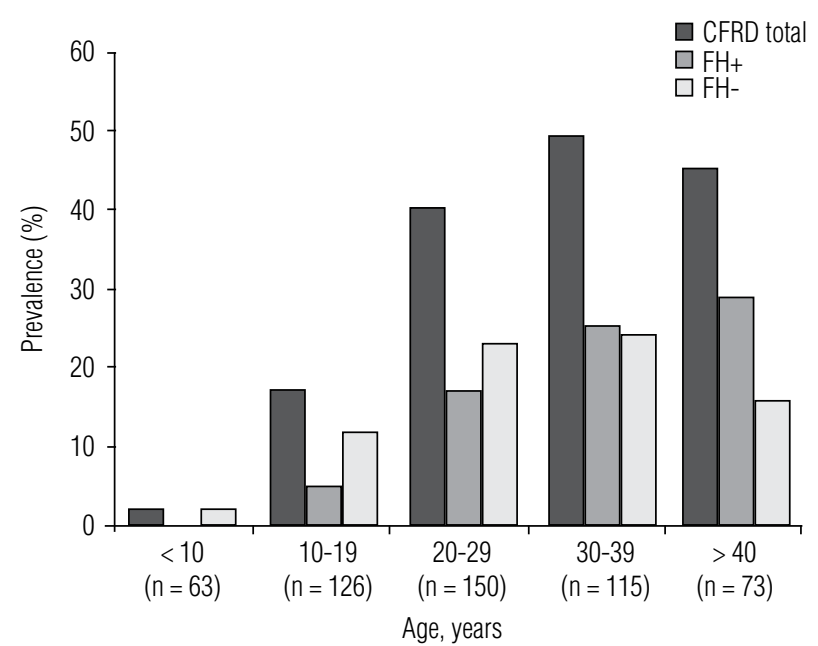

Figure 1. Prevalence of CFRD based on 2005-2008 data for all patients in each age group followed up at the University of Minnesota. Data on all CFRD patients (CFRD total) and separated by fasting glycemia, with fasting hyperglycemia $(\mathrm{FH}+)$ and without fasting hyperglycemia (FH-). Adapted from ref. 17

In the 1997 consensus, the American Diabetes Association included CFRD in the diabetes mellitus classification among "other types of diabetes - exocrine pancreas diseases" (7).

The importance of CFRD detection and treatment has been highlighted in recent years due to its association with a six-fold increase in CF morbidity and mortality. Clinical condition deteriorates, possibly two to six years before diagnosis (8).

Diabetes in CF is generally asymptomatic and may remain undetectable for up to four years prior to diagnosis (9), and because of this, it is necessary to utilize the oral glucose tolerance test (oGTT) as a screening tool for early detection (10).

Throughout recent years, several studies and consensuses have focused on this condition, adding infor- mation on the epidemiology, pathophysiology, prognosis and treatment of CFRD. The main aspects of these new concepts, as well as the current recommendations for CFRD diagnosis and follow-up, will be presented in this report.

\section{DEFINITION AND DIAGNOSIS OF CFRD - AN EVOLVING VISION}

CFRD is part of the set of abnormalities in glucose tolerance, which goes from IGT to CFRD (11) (Figure 2).

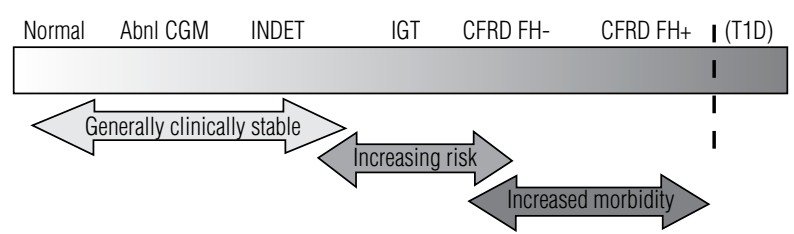

Figure 2. Glucose tolerance spectrum in CF. In contrast with DM type 1 patient, insulin secretion is never totally absent in CFRD. Clinical deterioration (pulmonary deterioration, underweight) is associated with worse glucose tolerance status. Abnl CGM: abnormal home continuous glucose monitoring, T1D: type 1 diabetes, INDET: indeterminate glycemia. Adapted from ref. 11.

The first important consensus, which initiated the standardizations of this issue, was the North American CFRD Committee Consensus, in 1998. In this document, CFRD was defined by 2-hour glycemia $\geq 200$ $\mathrm{mg} / \mathrm{dL}$ in the oGTT and it was suggested that patients with diabetes should be divided between those with or without fasting hyperglycemia $(\mathrm{FH})$, respectively, fasting glycemia $\geq 126$ or $<126 \mathrm{mg} / \mathrm{dL}$ (Figure 1 ). This classification was based on the fact that the prognosis could be different in the two groups. Screening for diagnostic recommendation was one annual random glycemia assessment. If glycemia was $\geq 126 \mathrm{mg} / \mathrm{dL}$, fasting glycemia test would be indicated. Diagnosis would be confirmed by two fasting glycemia measurements greater than $126 \mathrm{mg} / \mathrm{dL}$, or one measurement greater than $126 \mathrm{mg} /$ $\mathrm{dL}$, associated with random glycemia greater than 200 $\mathrm{mg} / \mathrm{dL}$. The oGTT was not recommended as a screening tool, and was utilized on patients without fasting hyperglycemia, but who presented potential symptoms for diabetes, such as unexplained polyuria or polydypsia, failure to maintain or gain weight (despite adequate nutritional support), slow growth, pubertal delay and inexplicable decline in pulmonary function (12).

Later on, oGTT became recommended annually, from 14 years of age on, as a screening test (13). Since 
the 2008 International Society for Pediatric and Adolescent Diabetes (ISPAD) consensus, initial age for the test has changed to 10 years old (14).

During the North American CF Consensus Conference in 2009, a new category was introduced to the CFRD diagnostic classification, called "indeterminate" (INDET) (15). Patients included in this category had normal glycemia at 0 and 120 minutes but, at intermediate times, presented glycemia greater than $200 \mathrm{mg} /$ $\mathrm{dL}$, or those who presented postprandial hyperglycemia detected by continuous glucose monitoring (CGM), in the absence of symptoms suggestive of diabetes (Table 1) (15). In the general population, the Diabetes Prevention Trial-Type 1 Study Group showed that individuals with the "indeterminate" profile are considered to be at risk for developing DM (16), and in children with $\mathrm{CF}$, it was associated with the early development of diabetes (17).
Some special situations, which are common in patients with CF, have begun to be considered to determine CFRD diagnosis $(11,15)$ (Figure 3):

- oGTT must be performed according to the ADA guidelines, in a period of six weeks free from acute exacerbations $(11,15)$.

- Hospitalization: patients in acute exacerbation and use of systemic corticoids should be investigated in the first 48 hours by means of fasting plasma glucose (FPG) and capillary glycemia controls (SMBG self-monitoring of blood glucose). In this condition, a patient would be considered diabetic if he or she presented fasting glycemia $\geq 126 \mathrm{mg} / \mathrm{dL}$ or postprandial glycemia $\geq 200 \mathrm{mg} / \mathrm{dL}$. When capillary glycemia levels are greater than $200 \mathrm{mg} / \mathrm{dL}$, blood samples should be collected for glycemia in order to confirm the diagnosis. This aspect reveals specific consideration for CF patients, or in other words, the interpretation of elevated

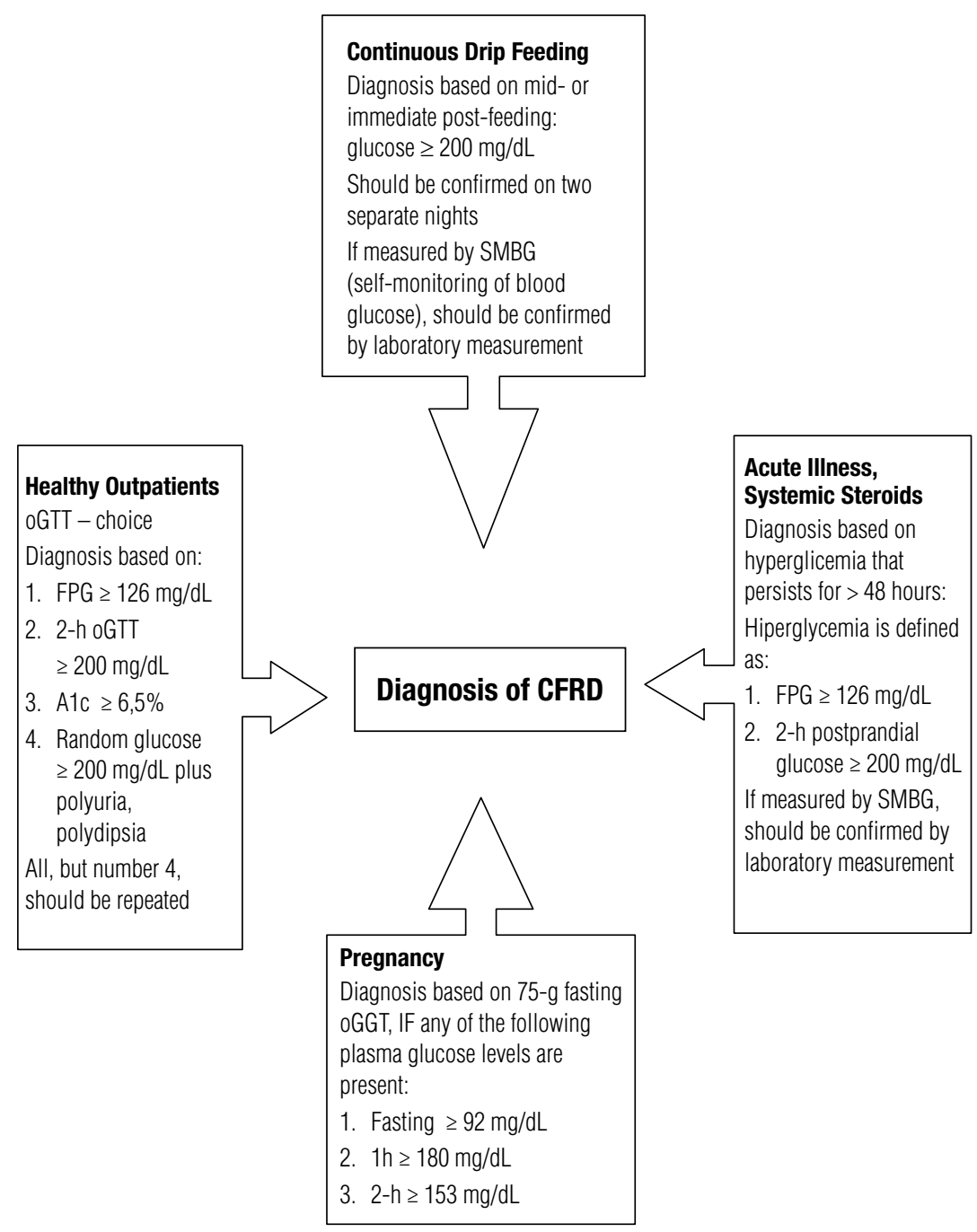

Figure 3. Diagnostic criteria for CFRD under different conditions (adapted from ref. 11). 
Table 1. Categories of oral glucose tolerance in CF as defined by the North American CF Consensus Conference (ref. 15)

\begin{tabular}{lcc}
\hline Category & FPG, $\mathbf{~ m g / d L}$ & 2 - hour PG, $\mathbf{~ m g / d L}$ \\
\hline NGT & $<126(7.0)$ & $<140(7.8)$ \\
INDET* $^{*}$ & $<126(7.0)$ & $140-199(7.8-11.1)^{*}$ \\
OGI & $<126(7.0)$ & $140-199(7,8-11,1)$ \\
$\begin{array}{l}\text { CFRD without Fasting } \\
\text { hiperglycemia (FPG) }\end{array}$ & $<126(7.0)$ & $\geq 200(11,1)$ \\
$\begin{array}{l}\text { CFRD with Fasting } \\
\text { hiperglycemia (FPG) }\end{array}$ & $\geq 126(7.0)$ & oGTT not necessary \\
\hline
\end{tabular}

* Oral glucose tolerance in fasting glycemia and in 2-hour glycemia concentration by oGTT, but intermediate values of $\mathrm{OGTT} \geq 200 \mathrm{mg} / \mathrm{dL}$ ( $11.1 \mathrm{mmol} / \mathrm{l})$, or postprandial hyperglycemia determined by continuous glucose monitoring (CGM) in the absence of symptoms.

The OGTT is performed by administering an oral glucose solution of $1.75 \mathrm{~g} / \mathrm{kg}$ of weight (maximum of 75 grams) to fasting patients. Fasting plasma glucose (FPG) and 2-hour plasma glucose $(\mathrm{PG})$ are measured. The patient should have consumed at least 150 grams per day of carbohydrates during the 3 days prior to the test $(600 \mathrm{kcal})$. Most CF patients consume much more than this on a daily basis. Figures in parentheses indicate millimol/iter.

NTG: normal glucose tolerance; INDET: indeterminate; OGI: oral glucose intolerance.

glycemia during the most severe periods of the disease. The recommendation for patients with CF considers that hyperglycemia, besides being a diagnostic criteria for diabetes, determines the onset of CFRD, even in patients hospitalized and ill. Cystic fibrosis is a disease associated with hyperglycemia, which is a reflex of insulin deficiency, even when associated with insulin resistance due to a recurring event. The definition of the disease by these criteria encourages early intervention and improves chronic complications $(10,11,15)$.

- Enteral nutrition: very frequently, patients with CF have to use enteral nutrition as nutritional support. In these cases, it is recommended that capillary glycemia control should be performed in the first infusion, during and after the termination of the diet, and at home, once a month. In the case of alterations, blood samples should be collected for plasma glycemia in order to confirm the diagnosis $(11,15)$.

- Pregnancy: oGTT should be performed during pregnancy planning in patients with CF. When pregnancy is confirmed, a new oGTT should be done immediately, if the patient does not have results within the normal range for six months prior to follow-up $(11,15)$. During pregnancy, oGTT should be performed between weeks 12 and 16, and again between weeks 24 and 28. Diagnostic levels following oral overload of glucose for gestational diabetes in $\mathrm{CF}$ are fasting glycemia $\geq 92 \mathrm{mg} / \mathrm{dL}$, glycemia after 1 hour $\geq 180 \mathrm{mg} / \mathrm{dL}$, and $\geq 153 \mathrm{mg} / \mathrm{dL}$ after 2 hours. Patients who are diagnosed with gestational diabetes should have another screening control at 6 and 12 weeks after conceiving.

According to the latest Consensus, it was determined that there is no need to separate patients with
CFRD in terms of presence or absence of fasting hyperglycemia $(11,15)$. In previous recommendations, patients without fasting hyperglycemia were not indicated for insulin therapy $(12,14)$, but more recent studies have shown the benefits of the early treatment of CFRD with insulin for both groups (with or without fasting hyperglycemia), thus justifying that it is unnecessary to separate the two groups, or to alter the diagnostic classification $(7,18)$.

CFRD is, in fact, the final period in a spectrum of progressive abnormalities in glucose tolerance. The first alterations may range from intermittent postprandial hyperglycemia, followed by oral glucose intolerance, to diabetes with or without fasting hyperglycemia. An isolated alteration in fasting glycemia is rare in $\mathrm{CF}$, and patients tend to maintain normal fasting glucose for a considerable time after the first 2-hour oGTT greater than $200 \mathrm{mg} / \mathrm{dL}$ (19). Such an alteration may be considered as a fluctuation in the degree of glucose tolerance, and may vary from one individual to another.

Another aspect to be taken into account is that the insulin sensitivity in CF may vary according to the patient's clinical condition, the presence of infection, nutritional status, and use of medications (mainly corticoids). A patient with CF who presented diabetes during a pulmonary exacerbation period may return to normal glucose tolerance values within weeks or months (11).

Hemoglobin AlC (HbAlc), considered a good diagnostic test for diabetes in the general population, should not be considered as a routine screening test for diagnosis in CF patients (10). Studies have shown a weak correlation between HbAlc and the degree of glucose tolerance. However, when $\mathrm{HbAlc}$ yields a high result, it should be taken into consideration in the diag$\operatorname{nosis}(20,21)$.

\section{INCIDENCE AND PREVALENCE}

Increased incidence and prevalence of DM and glucose intolerance in $\mathrm{CF}$ are greater than in any other group of the same age, including Pima Indians (22). An age-dependent elevation of $4 \%-9 \%$ in prevalence per year was found in Denmark (23). The incidence depends on the monitoring and diagnostic criteria utilized by the medical services, and may be underestimated in centers which do not screen all patients.

Increased prevalence involves older individuals, but CFRD has been diagnosed in even younger patients, 
including during the first year of life $(24,25)$. At the Center for Cystic Fibrosis of Minnesota University, where oGTT is done annually in all patients 5 years of age or older, prevalence of DM was $9 \%$ for those between 5 and 10, peak incidence was between 20 and 30 years of age, and it affected $45 \%-50 \%$ of the patients around 40 years old (17). In Denmark, where oGTT is performed annually from infancy on, $50 \%$ of the patients had diabetes at around 30 years of age (26). In the European CF Epidemiology register, the prevalence of DM among children and adolescents with CF varied $5 \%$ (10-14 years old) to $13 \%$ (15-19 years of age) (27). A prospective data compilation in Ireland found a similar scenario, with $69 \%$ normal tolerance; $14 \%$ glucose intolerance; and CFRD in $17 \%$ of the patients between 10 and 19 years of age (28).

There are studies that correlate the greater prevalence of CFRD with mutations in delta F508 gene, principally when in homozygosis (29). In Europe and the United States, this mutation is present in as many as $70 \%-90 \%$ of the patients studied. Such rates could therefore justify the high prevalence of CFRD in these regions. In Brazil, this mutation has been described as present in 33\% to 52\% in São Paulo (30-32), 49\% in Rio Grande do Sul, and 27\% in Santa Catarina (31).

In relation to the prevalence of CFRD among us, there is little information available, with prevalence ranging from $4.8 \%$ to $33 \%$, depending on age and type of diagnostic screening test used (33-35). In our practice, at Hospital da Santa Casa de São Paulo, the oGTT has been performed annually in all patients 10 years old and over, since 2000. In 2009, we began the study screening children from 8 years of age on. In a preliminary data compilation involving 63 patients until December 2010 , the prevalence of altered test results in the age group of 8-10 years was $18.2 \%$ (for IGT and CFRD), and $26.7 \%$ in patients older than $10(36)$.

These data suggest that our population has the same trend of high CFRD prevalence, as evidenced in the literature, and indicates the need to carry out screening procedures for early detection.

\section{PATHOPHYSIOLOGY OF CFRD}

There are studies that correlate the occurrence of CFRD with mutations associated with more severe diseases, such as phenylalanine 508 deletion (delta F508), and pancreatic exocrine insufficiency (29). There is no correlation with gene susceptibility to DM type 1 , such as HLA class II (37) or VNTR (29), but, as in DM type 2 , a correlation has been found with genes linked with the tumor necrosis factor $(37)$, heat shock protein $(37,38)$, and calpain 10 (39). Occasionally, DM type 1 has been found in CF $(40,41)$.

Pancreatic alterations are due to the abnormal function of the chloride channels in $\mathrm{CF}$, which results in viscous secretion, causing obstruction of the exocrine pancreas with progressive fibrosis and fat infiltration. This mechanism may lead to the destruction and rupture of the islets, which, in turn, lead to loss of beta, alpha and polypeptide cells. However, postmortem studies have not found a great loss of islets in CFRD patients when compared with patients who had normal glucose tolerance. On the other hand, amyloid polypeptide, which is also characteristic of DM type 2, was found in $69 \%$ of the CFRD patients, and was absent in the non-diabetics ones $(42,43)$.

The primary defect that leads to diabetes is severe, but not absolute, insulin deficiency $(6,23)$. Fasting insulin and peptide $\mathrm{C}$ may be normal, but there is a delay in the peak secretion of insulin during the oGTT. Peak insulin secretion in normal individuals occurs at 30 to 60 minutes, while in CFRD patients it is observed between 90 and 120 minutes. This delay in insulin secretion in the oGTT is related to the loss of the first phase of insulin secretion, which was found in CF patients, even in those who still presented normal glucose tolerance (44).

Another issue that is discussed in relation to the development of CFRD is the presence of insulin resistance. A clamp study found hepatic insulin resistance with elevated glucose production (in fasting, as well as in response to insulin infusion), occurring equally in diabetic patients and in those who had totally normal fasting glucose levels (44). It has been hypothesized that increased energy needs of CF patients create a physiological balance between elevated hepatic glucose production and high glucose demand $(43,44)$. In addition, the frequent use of glucocorticoids and constant infections may worsen this condition. However, despite these aspects, the insensitivity to insulin is not as important as its deficiency in the development of CFRD.

\section{PROGNOSTIC IMPLICATIONS OF CFRD}

\section{Mortality and pulmonary function}

A 1988 study showed data in which $25 \%$ of the CFRD patients reached the age of 30 , compared with $60 \%$ of 
the CF patients without diabetes (45). It was the first time a study showed greater mortality in CF and diabetes patients. From then on, other studies have demonstrated that the diagnosis of DM in CF patients is associated with worsening of nutritional condition, more severe lung disease, and higher mortality $(45,46)$.

The impact of diabetes on pulmonary function seems to be the most important morbidity in these patients. Both insulin deficiency and hyperglycemia negatively affect pulmonary disease in CF. Nutritional condition and pulmonary function begin to deteriorate several years prior CFRD diagnosis, a period in which minimal hyperglycemia is present $(9,11)$. Modest increases in glycemia $(\geq 144 \mathrm{mg} / \mathrm{dL}$ ) may influence pulmonary function, as they promote a glycemic increase in the bronchial tree, which may facilitate the growth of respiratory pathogens (47). Fasting hyperglycemia $(\mathrm{FH})$ does not appear to be relevant in the progression of the disease, as there was no difference in pulmonary function and nutritional condition among CFRD patients with and without $\mathrm{FH}(7)$.

The level of pulmonary deterioration is directly related to the severity of insulin deficiency. In a 4 -year follow-up, patients with glucose intolerance after the oGTT showed greater pulmonary function loss than those with normal glucose tolerance. CFRD patients, with or without $\mathrm{FH}$, had an even greater loss (48).

A longitudinal evaluation at a CF center compared the mortality of diabetes patients in 1992-97 and 2003-2008, and found a decrease in mortality of over $50 \%$ between the two (from 6.9 to 3.2 deaths per 100 female patients, and from 6.5 to 3.8 for male patients) (7). This improvement was attributed to earlier diagnosis and more aggressive insulin treatment in the later period (7).

CF pulmonary function, dependent on weight and maintenance of lean mass, is affected by insulin deficiency, which compromises nutritional condition, generating a catabolic state, with breakdown of fat and proteins (49). In a recent controlled, random, placebo-controlled, multicenter study, it was demonstrated that insulin therapy was able to revert chronic weight loss in adult CFRD patients, with and without FH. This finding put an end to the old discussion about when insulin should be prescribed in cases of light forms of diabetes (without $\mathrm{FH}$ ), considering that treatment should be initiated in the earliest stages of the disease (18).

As for patients with oral glucose intolerance or the so-called "indeterminated diabetes", the benefits of in- sulin therapy have not yet been proven. Small studies done in adults and children suggest that insulin should be recommended and introduced in these cases, but more studies are necessary before any modification can be suggested $(50,51)$.

\section{Macro and microvascular complications}

In spite of the increase in survival among CFRD patients, there is no record of CF patients who succumbed to atherosclerotic cardiovascular disease. This is due to the fact that the cholesterol levels in these patients are generally low, despite a diet rich in saturated fat (52). Low cholesterol levels may be attributed to poor absorption of fats, and may be even intrinsically correlated with the basic defect in the CF gene, as cholesterol levels are low even in well-nourished patients.

Microvascular complications, such as blindness, glaucoma, hypertension and renal failure have been described in patients with CFRD $(53,54)$. In Denmark, $36 \%$ of the patients who have had diabetes for over 10 years present retinopathy (55). A study that evaluated 285 patients with CFRD did not find complications in patients who presented normal fasting glycemia. In those who presented fasting hyperglycemia, microvascular complications were rare with less than 10 years of diabetes progression. In patients with $\mathrm{FH}$ and over 10 years with the disease, $14 \%$ had microalbuminuria, 16\% retinopathy, 55\% neuropathy and $50 \%$ gastropathy $(53)$.

Despite the fact that microvascular complications in CFRD are less frequent than in other types of DM, it is important that these complications are screened 5 years after the diagnosis $(10,11,15)$.

\section{TREATMENT OF CFRD}

\section{Nutritional orientation}

There is no place for caloric restriction in the nutritional management of CF patients with CFRD. Maintenance of an adequate caloric balance to preserve the body mass index (BMI) is essential for the health and survival of CF patients. CFRD diagnosis should not alter the usual CF dietary recommendations (Table 2).

Maintenance of the BMI over 50 percent, for gender and age between 2 and 20 years old, is considered the ideal goal. For adult females, it would be $>22 \mathrm{~kg} / \mathrm{m}^{2}$ and for males $>23 \mathrm{mg} / \mathrm{m}^{2}(56)$. 
Table 2. Differences in the diet management of DM1 (diabetes mellitus type 1) and DM2 (diabetes mellitus type 2) versus CFRD recommendation (adapted from ref. 57)

\begin{tabular}{|c|c|c|}
\hline Nutrient & DM1 and DM2 & CFRD \\
\hline Calories & $\begin{array}{l}\leq 100 \% \text { of normal diet for age and gender } \\
\text { Control or restrict calories to prevent excess weight }\end{array}$ & $\begin{array}{l}\text { Generally needs from } 120 \%-150 \% \text { of the basal needs for age and } \\
\text { gender to prevent underweight }\end{array}$ \\
\hline Fat & $<35 \%$ of total energy & $40 \%$ of total energy \\
\hline Refined sugar & Up to $10 \%$ of the total energy & No restriction \\
\hline Carbohydrate & $46 \%-60 \%$ of total energy & $46 \%-60 \%$ of total energy \\
\hline Dietary fiber & $\begin{array}{l}\text { No quantitative recommendation but } \\
\text { encouraged due to beneficial effects }\end{array}$ & $\begin{array}{l}\text { Recommended for the well-nourished, but in the undernourished can } \\
\text { impair energy intake }\end{array}$ \\
\hline Protein & $\begin{array}{l}10 \%-20 \% \text { of the total energy, but not over }>1 \mathrm{~g} \text { per } \mathrm{kg} \text { of body weight } \\
\text { per day }\end{array}$ & $200 \%$ of reference nutrient intake \\
\hline Salt & Ingested $\leq 6 \mathrm{~g} /$ day & Increased requirement, without restriction \\
\hline
\end{tabular}

\section{Insulin therapy}

Currently, insulin is the only medical therapy recommended for CFRD $(10,11,15)$. Due to the variables, which are extremely dependent on the type of CF progression (degree of insulin deficiency, utilization of enteral nutrition, pulmonary function impairment, use of associated medications), insulin therapy regimens should always follow the patient's needs. These regimens go from the utilization of rapid or ultra-rapid-action insulin, to suppress postprandial hyperglycemia, to the use of the basal-bolus regimen in multiple doses, and even to an insulin infusion system for the most insulin-deficient patients.

A study by Hardin and cols. reported 10 young adults treated with, and monitored by, the Continuous Glucose Infusion System (CIS) for a period of 6 months. All of them presented an improvement in BMI and pulmonary function, and a reduction in corporal catabolism (57). Other studies before that had already suggested that insulin stabilizes pulmonary function and improves nutritional condition $(7,18)$.

We did not find studies showing benefits of insulin in children and adolescents with CF and glucose intolerance.

\section{THERAPY WITH ORAL AGENTS}

The oral agents for diabetes are not recommended in CFRD $(10,11,15)$, but there are some data in the literature on their use in this situation.

Repaglinide: insulin secretagogue, increased endogenous insulin concentration, but was less effective than the rapid-action insulin in the control of postprandial hyperglycemia in an experimental study (58).
Sulfonylureas: block and inhibit chloride channels and cause hypoglycemic problems.

Agents that increase sensibility to insulin may not be effective as a monotherapy, as insulin resistance is not the main etiology in CFRD (59). Metformin: causes, in most patients, intolerable collateral effects, such as nauseas, diarrhea and abdominal discomfort (60). Thiazolidinediones: were recently associated with osteoporosis.

In conclusion, in the last few years, there has been a rapid increase in the survival of cystic fibrosis patients due to an improvement in diagnosis and treatment conditions. With the increased lifespan, the comorbidities associated with the disease, which were previously unknown or rare, have also begun to appear. Among them, CFRD appears as the most frequent and most potentially severe one, worsening patient quality of life and prognosis.

The presence of CFRD is clinically difficult to detect, as it may be asymptomatic for several years prior to diagnosis. Its high frequency, the absence of signs and symptoms in the initial phases, and risk of association with clinical deterioration, justify the studies that have been done on the diagnosis and treatment of this disorder.

Currently, a standardized routine is advocated to achieve this aim, with annual screening for early detection of CFRD with the oral glucose tolerance test for all cystic fibrosis patients, beginning at 10 years of age. CFRD assessment should also be carried out among patients younger than 10 years of age who present symptoms suggestive of DM, and in situations where insulin resistance is temporarily increased (pulmonary exacerbations, enteral nutrition, pregnancy, use of corticoids). 
The early treatment with insulin should be instituted and individualized as soon as the diagnosis is confirmed, which will result in an important improvement in the clinical conditions and survival of CF patients.

The presence of another diagnosis - Diabetes - for the families and the patients with CF, is frequently difficult to accept and, sometimes, devastating. In addition to the impact of the chronic and incurable disease, there is the need for introduction of a treatment consisting of daily injections, for a patient who already has an intense daily nutrition and medication routine. To make matters worse, screening produces a diagnosis before the symptoms appear, which generates great resistance and a tendency for low adherence to insulin treatment.

In this case, the existence of a multidisciplinary team, with a pneumologist, a physical therapist, a psychologist and a nutritionist, in addition to the endocrinologist, is essential to promote the understanding of, and the adherence to the treatment and control of CFRD.

Despite all the advances that took plance in such a short period of time, many doubts and controversies still persist in relation to to this very peculiar form of diabetes. Answers may be provided by new studies in the next years.

Disclosure: no potential conflict of interest relevant to this article was reported.

\section{REFERENCES}

1. The cystic fibrosis genotype-phenotype consortium. Correlation between genotype and phenotype in patients with cystic fibrosis. N Engl J Med. 1993;329:1308-13.

2. Riordan JR, Rommens JM, Kerem B, Alon N, Rozmahel R, Grzelczar $\mathrm{Z}$, et al. Identification of the cystic fibrosis gene: cloning and characterization of the complementary DNA. Science. 1989;245:1066-73.

3. Cystic Fibrosis Foundation Patient Registry 2007 Annual Data Report, Bethesda, MD.

4. Adler Al, Shine BS, Chamnan P, Haworth CS, Bilton D. Genetic determinants and epidemiology of cystic fibrosis-related diabetes: results from a British cohort of children and adults. Diabetes Care. 2008;31:1789-94.

5. Brennan AL, Geddes DM, Gyi KM, Baker EH. Clinical importance of cystic fibrosis related diabetes. J Cyst Fibros. 2004;3:209-22.

6. Moran A, Dunitz J, Nathan B, Saeed A, Holme B, Thomas W. Cystic fibrosis-related diabetes: currents trends in prevalence, incidence, and mortality. Diabetes Care. 2009;32:1626-31.

7. American Diabetes Association. Clinical Practice Recommendations 1999. Diabetes Care. 1999;22(Suppl 1):S7.

8. O'Riordan SM, Robinson PD, Donaghue KC, Moran A. ISPAD Clinical Practice Consensus Guidelines 2009 Compendium: management of cystic fibrosis-related diabetes in children and adolescents. Pediatr Diabetes. 2009;10:43-50.
9. Rolon MA, Benali K, Munck A, Navarro J, Clement A, Tubiana-Rufi N, et al. Cystic fibrosis-related diabetes mellitus: clinical impact of prediabetes and effects of insulin therapy. Acta Paediatr. 2001;90:860-7.

10. Moran A, Brunzell C, Cohen CR, Katz M, Marshal CB, Onady G, et al. Clinical Care Guidelines for Cystic Fibrosis-Related Diabetes. A position statement of the American Diabetes Association and a clinical practice guideline of the Cystic Fibrosis Foudation, endorsed by the Pediatric Endocrine Society. Diabetes Care. 2010;33:2697-708.

11. Moran A, Becker D, Casella SJ, Gottlieb PA, Kirman MS, Marshal $B C$, et al. Epidemiology, pathophysiology, and prognostic implications of cystic fibrosis-related diabetes. A technical review. Diabetes Care. 2010;33:2677-83.

12. Moran A, Hardin D, Rodman D, Allen HF, Beall RJ, Borowitz D, et al. Diagnosis, screening and management of cystic fibrosis related diabetes mellitus: a consensus conference report. Diabetes Res Clin Pract. 1999;45:61-73.

13. Costa M, Potvin S, Berthiaume Y, Gauthier L, Jeanneret A, Lavoie A, et al. Diabetes: a major co-morbity of cystic fibrosis. Diabetes Met. 2005;31:221-32.

14. O'Riordan MS, Robinson PD, Donaghue KC, Moran A. Management of cystic fibrosis-related diabetes. Pediatric Diabetes. 2008:9(Partl):338-44.

15. American Diabetes Association. Clinical Practice Recommendations - 2010. Diabetes Care 2010:33( Suppl1):S1-S100.

16. Sosenko JM, Palmer JP, Rafkin-Mervis L, Krischer JP, Cuthberton D, Mahon J, et al. Diabetes Prevention Trial-Tipe 1 Study Group. Incident dysglicemia and progression to type 1 diabetes among participants in the Diabetes Prevention Trial Type 1. Diabetes Care. 2009;32:1603-7.

17. Ode $\mathrm{KL}$, Frohnert $\mathrm{B}$, Laguna T, Phillips J, Holme B, Moran A, et al. Oral glucose tolerance testing in children with cystic fibrosis. Pediatric Diabetes 2010;11:487-92.

18. Moran A, Pekow P, Grover P, Zorn M, Slovis B, Pilewski J, et al. Cystic Fibrosis Related Diabetes Therapy Study Group. Insulin therapy to improve BMI in cystic fibrosis-related diabetes without fasting hyperglycemia: results of the cystic fibrosis related diabetes therapy trial. Diabetes Care. 2009;32:1783-8.

19. Lombardo F, De Luca F, Rosano M, Sferlazzas C, Lucanto C, Arrigo $T$, et al. Natural history of glucose tolerance, beta-cell function and peripheral insulin sensitivity in cystic fibrosis pacients with fasting euglycemia. Eur J Endocrinology. 2003:149:53-9.

20. Godbout A, Hammana I, Potvin S, Mainville D, Rakel A, BerthiaumeY, et al. No relashionship between mean plasma glucose and glycated haemoglobin in patients with Cystic Fibrosis-related diabetes. Diabetes Metab. 2008;34:568-73.

21. Franceze D, Valerio G, Buono P, Spagnuolo MI, Sepe A, Mozzillo $E$, et al. Continuous glucose monitoring system in the screening of early glucose derangements in children and adolescents with cystic fibrosis. J Pediatr Endocrinol. Metab 2008;21:109-16.

22. McCance DR, Hanson RL, Charles MA, Jacobsson LT, Pettitt DJ, Bennett $P$, et al. Comparison of tests for glycated haemoglobin and fasting and two-hour plasma glucose concentrations as diagnostic methodsfor diabetes. BMJ. 1994;308:1323-8.

23. Lanng S, Hansen A, Thorsteinsson B, Nerup J, Koch C. Glucose tolerance in patients with cystic fibrosis: five-year prospective study. BMJ. 1995;311:655-9.

24. Casas L, Berry DR, Logan K, Copeland KC, Royall JA. Cystic fibrosis-related diabetesin an extremely young patient. J Cyst Fibros. 2007;6:247-9.

25. Gelfand IM, Eugster EA, Haddad NG. Infancy-onset cystic fibrosis-related diabetes. Diabetes Care. 2005;28:2593-4.

26. Lanng S. Glucose intolerance in cystic fibrosis patients. Paediatr Respir Rev. 2001;2:253-9. 
27. Koch C, Rainisio M, Madessani U, Harms HK, Hodson ME, Mastella $\mathrm{G}$, et al. Presence of cystic fibrosis-related diabetes mellitus is tightly linked to poor lung function in patients with cystic fibrosis: data from the European Epidemiologic Registry of Cystic Fibrosis. Pediatr Pulmonol. 2001;32:343-50.

28. O'Riordan S, Hoey SGH, Costigan C. Demographics and prevalence of glucose intolerance and cystic fibrosis related diabetes in 167 cystic fibrosis children. Diabetes. 2006;55:A224.

29. O'Riordan SGA, Ennis S, George S, Hand E, Costigan C, Murphy $\mathrm{N}$, et al. Genetics of cystic fibrosis related diabetes and nondiabetes. Horm Res. 2007;68(suppl 1):44-69.

30. Ribeiro JC, Ribeiro MAGO, Ribeiro AF. Controvérsias na fibrose cística - do pediatra ao especialista. J Pediatr (Rio J). 2002;78(Supl.2):S171-86.

31. Raskin S, Phillips JA 3rd, Krishnamani MR, Vnencak-Jones C, Parker RA, Rozov T, et al. DNA analysis of cystic fibrosis in Brazil by direct PCR amplification from Guthrie cards. Am J Med Gen. 1993;46:665-9.

32. Martins CSB, Ribeiro AF, Costa FF. Frequency of the cystic fibrosis DF508 mutation in a population from São Paulo State, Brazil. Braz J Med Biol Res. 1993;26:1037-40.

33. Manna TD, Setian N, Rodrigues JC. O diabetes melito na fibrose cística: uma comorbidade cada vez mais freqüente. Arq Bras Endocrinol Metab. 2008;52:(2):188-97.

34. Castro FA, Fernandes MI, Júnior RM, Foss MC. Study of the frequency of diabetes mellitus and glucose intolerance in patients with cystic fibrosis. J Pediatr. 2001;77(4):321-6.

35. Alvarez AE, Ribeiro AF, Hessel G, Bertuzzo CS, Ribeiro JD. Cystic fibrosis at a Brazilian center of excellence: clinical and laboratory characteristics of 104 patients and their association with genotype and disease severity. J Pediatr. 2004;80(5):371-9.

36. Noronha RM, Calliari LEP, Damasceno N, Muramato LH, Kochi C, Longui CA, et al. Valor do GTT oral (GTTo) na triagem do diagnóstico do diabetes mellitus relacionado a fibrose cística (DMRFC). Arq Bras Endocrinol Metab. 2011;55(supl. 1):S1.

37. Lanng S, Thorsteinsson B, Pociot F, Marshall MO, Madsen HO, Schwartz M, et al. Diabetes mellitus in cystic fibrosis: genetic and immunological markers. Acta Paediatr Scand. 1993;82:150-4.

38. Jensen P, Johansen HK, Carmi P, Hoiby N, Cohen IR. Autoantibodies to pancreatic hsp60 precede the development of glucose intolerance in patients with cystic fibrosis. J Autoimmun. 2001;17:165-72.

39. Derbel S, Doumaguet C, Hubert D, Mosnier-Pudar H, Grabar S, Chelly J, et al. Calpain 10 and development of diabetes mellitus in cystic fibrosis. J Cyst Fibros. 2006;5:47-51.

40. Atlas AB, Finegold DN, Becker D, Trucco M, Kurland G. Diabetic ketoacidosis in cystic fibrosis. AJDC. 1992;146:1457-8.

41. Swartz LM, Laffel LM. A teenage girl with cystic fibrosis-related diabetes, diabetic ketoacidosis, and cerebral edema. Pediatr Diabetes. 2008;9:426-30.

42. Couce M, O'Brien TD, Moran A, Roche PC, Butler PC. Diabetes mellitus in cystic fibrosis is characterized by islet amyloidosis. $J$ Clin Endocrinol Metab. 1996;81:1267-72.

43. Moran A, Diem P, Klein DJ, Levitt MD, Robertson RP. Pancreatic endocrine function in cystic fibrosis. J Pediatr. 1991;118:715-23.

44. Hardin DS, LeBlanc A, Para L, Seilheimer DK. Hepatic insulin resistance and defects in substrate utilization in cystic fibrosis. Diabetes. 1999;48:1082-7.
45. Finkelstein SM, Wielinski CL, Elliott GR, Warwick WJ, Barbosa J, Wu SC, et al. Diabetes mellitus associated with cystic fibrosis. J Pediatr. 1988;112:373-7.

46. Marshall BC, Butler SM, Stoddard M, Moran AM, LiouTG, Morgan WJ. Epidemiology of cystic fibrosis-related diabetes. J Pediatr. 2005;146:681-7.

47. Brennan AL, Gyi KM, Wood DM, Johnson J, Holliman R, Baines DL, et al. Airway glucose concentrations and effect on growth of respiratory pathogens in cystic fibrosis. J Cyst Fibros. 2007;6:101-9.

48. Milla CE, Warwick WJ, Moran A. Trends in pulmonary function in patients with cystic fibrosis correlate with the degree of glucose intolerance at baseline. Am J Resp Crit Care Med. 2001;162:891-5.

49. Rafii M, Chapman K, Stewart C, Kelly E, Hanna A, Wilson DC, et al. Changes in response to insulin and the effects of varying glucose tolerance on whole-body protein metabolism in patients with cystic fibrosis. Am J Clin Nutr. 2005;81:421-6.

50. Mozzillo E, Franzese A, Valerio G, Sepe A, De Simone I, Mazzarella G, et al. One-year glargine treatment can improve the course of lung disease in children and adolescents with cystic fibrosisand early glucose derangements. Pediatr Diabetes. 2009;10:162-7.

51. Bizzarri C, Lucidi V, Ciampalini P, Bella S, Russo B, Cappa M. Clincial effects of early treatment with insulin glargine in patients with cystic fibrosis and impaired glucose tolerance. J Endocrinol Invest. 2006;29:1-4.

52. Figueroa V, Milla C, Parks EJ, Schwarzenberg SJ, Moran A. Abnormal lipid concentrations in cystic fibrosis. Am J Clin Nutr. 2002;75:1005-11.

53. Schwarzenberg SJ, Thomas W, Olsen TW, Grover T, Walk D, Milla C, et al. Microvascular complications in cystic fibrosis-related diabetes. Diabetes Care. 2007;30:1056-61.

54. van den Berg JM, Morton AM, Kok SW, Pijl H, Conway SP, Heijerman HG. Microvascular complications in patients with cystic fibrosis-related diabetes (CFRD). J Cyst Fibros. 2008;7:515-9.

55. Andersen HU, Lanng S, Pressler T, Laugesen CS, Mathiesen ER. Cystic fibrosis-related diabetes - The presence of microvascular diabetes complications. Diabetes Care. 2006;29:2660-3.

56. Starllings VA, Stark LJ, Robinson KA, Ferranchak AP, Quinton H. Clinical Practice Guidelines on Growth and Nutrition Subcommitte, Ad Hoc Working Group. For de Clinical Practice Guidelines on Growth and Nutrition Subcommitte. Evidenced-based practice nutrition recommendation-related management of children and adults with cystic fibrosis and pancreatic insufficiency: results of a systemic review. J Am Diet Assoc. 2008;108:832-9.

57. Hardin DS, Rice J, Rice M, Rosenblatt R. Use of the insulin pump in treating cystic fibrosis related diabetes. J Cyst Fibros. 2009;8:174-8.

58. Moran A, Phillips J, Milla C. Insulin and glucose excursion following premeal insulin lispro or repaglinide in cystic fibrosis-related diabetes. Diabetes Care. 2001;24:1706-10.

59. O'Riordan SM, Dattani MT, Hindmarsh PC. Cystic fibrosis-related diabetes in childhood. Horm Res Paediatr. 2010;73:15-24.

60. Rosenecker J, Eichler I, Barmeier H, von der Hardt H. Diabetes mellitus and cystic fibrosis: comparison of clinical parameters in patients treated with insulin versus oral glucose-lowering agents. Pediatr Pulmonol. 2001;32:351-5. 